\title{
EFFECTS OF NEOSTIGMINE AND PYRIDOSTIGMINE ON SERUM CHOLINESTERASE ACTIVITY
}

\author{
R.K. Mirakhur, T.D. Lavery, L.P. Briggs and R.S.J. Clatke
}

\begin{abstract}
Serum cholinesterase activities were measured for 270 minutes in patients following administration of neostigmine or pyridostigmine for the reversal of pancuronium block in groups of seven patients each. The enzyme activities were significantly depressed by neostigmine for four hours and by pyridostigmine throughout the whole period of study. Whereas the immediate effects of neostigmine were more intense, the effects of pyridostigmine beyond the first 30 minutes were more profound. The clinical relevance of these findings is discussed.
\end{abstract}

KEY WORDS: ENZYMES, serum cholinesterase; ANTAGONISTS, NEUROMUSCULAR RElaXANTS, neostigmine, pyridostigmine.

Although Neostigmine is the anticholinesterase drug commonly employed to reverse residual non-depolarising neuromuscular block, pyridostigmine has advantages such as a longer duration of action and a greater therapeutic ratio. ${ }^{1}$ These drugs are generally believed to antagonise non-depolarising block by inhibiting the enzyme acetylcholinesterase. They have also been reported by some observers to inhibit serum cholinesterase (pseudocholinesterase). ${ }^{2-4}$ In some of these studies pseudocholinesterase activity has been measured for only short periods while in others anticholinesterase drugs have been administered following succinylcholine (to prolong its effect), a situation not commonly arising in current anaesthetic practice.

While studying the pharmacokinetics of pyridostigmine we measured the serum cholinesterase activity for four and a half hours and report these in the present paper. Plasma cholinesterase activity was similarly measured following administration of neostigmine for a similar period of time. The anticholinesterase drugs were administered for the routine antagonism of residual neuromuscular block.

R.K. Mirakhur, M.D., Ph.D., F.F.A.R.C.S., Consultant Anaesthetist, Royal Victoria Hospital, Belfast, T.D. Lavery, F.I.M.L.S., Biochemistry Laboratory, Royal Victoria Hospital, Belfast; L.P. Briggs, L.R.C.P. \& S.I., F.F.A.R.C.S., Senior Tutor, Department of Anaesthetics, The Queen's University of Belfast; R.S.J. Clarke, M.D., Ph.D., F.F.A.R.C.S., Professor of Clinical Anaesthetics, The Queen's University of Belfast.

\section{Patients AND METhodS}

The study was carried out in 14 adult patients of ASA Grade 1 undergoing elective surgery. The reversal of neuromuscular block was a part of the anaesthetic technique. The nature of the study was explained to the patients and their informed consent was obtained for withdrawal of blood samples. Their ages ranged from 21 to 66 years (mean 46 years) and weights from 50 to $85 \mathrm{~kg}$ (mean $64 \mathrm{~kg}$ ). None of the patients had any hepatic, renal, metabolic, endocrine or neuromuscular disease or any electrolyte abnormalities and none was receiving any drugs known to affect serum cholinesterase levels.

Premedication consisted of diazepam 10 $15 \mathrm{mg}$ given orally $60-90$ minutes preoperatively. Anaesthesia was induced with thiopentone $4-5 \mathrm{mg} \cdot \mathrm{kg}^{-1}$ followed by pancuronium 0.1 $\mathrm{mg} \cdot \mathrm{kg}^{-1}$ to facilitate tracheal intubation and to provide muscle relaxation during operation. Fentanyl or fentanyl-droperidol were administered as required to maintain anaesthesia along with 66 per cent nitrous oxide in oxygen. Ventilation was controlled throughout the operation. Arterial blood gas tensions were measured and ventilation was adjusted, if necessary, to keep the $\mathrm{Pa}_{\mathrm{CO}_{2}}$ between 4.66 and $5.98 \mathrm{kPa}$ (35 and $45 \mathrm{~mm} \mathrm{Hg}$ ).

A venous blood sample was withdrawn from one of the antecubital veins before the administration of the antagonists for estimation of serum cholinesterase activity. Residual neuromuscular block was antagonised by either neostigmine

Can. Anaesth. Soc. J., vol. 29, no. 1, January 1982 
TABLE I

Percentage Inhibition of Serum Cholinesterase Following Neostigmine or Pyridostigmine Administration

\begin{tabular}{|c|c|c|c|c|c|c|c|c|c|c|c|c|c|c|c|}
\hline & \multirow{3}{*}{$\begin{array}{c}\text { Mean } \\
\text { age } \\
(\mathrm{yr})\end{array}$} & \multirow{3}{*}{$\begin{array}{c}\text { Mean } \\
\text { weight } \\
\text { (kg) }\end{array}$} & \multirow{3}{*}{$\begin{array}{c}\text { Mean } \\
\text { initial } \\
\text { level } \\
(\mathrm{IU} / \mathrm{ml})\end{array}$} & \multirow{3}{*}{$\begin{array}{l}\text { Per cent of } \\
\text { control at } \\
\text { maximum } \\
\text { inhibition }\end{array}$} & \multirow{3}{*}{$\begin{array}{l}\text { Mean } \\
\text { time } \\
\text { to } I_{50} \\
\text { (min) }\end{array}$} & \multicolumn{10}{|c|}{$\begin{array}{c}\text { Serum cholinesterase } \\
\text { (Per cent of control level) }\end{array}$} \\
\hline & & & & & & \multicolumn{10}{|c|}{ Minutes } \\
\hline & & & & & & 1 & 5 & 10 & 20 & 30 & 60 & 120 & 180 & 240 & 270 \\
\hline Neostigmine & 44 & 61 & 2.56 & 7 & 20 & 7 & 23 & 37 & 49 & 57 & 78 & 87 & 92 & 95 & 100 \\
\hline Pyridostigmine & 47 & 66 & 2.58 & 25 & 20 & 29 & 31 & 38 & 50 & 54 & 60 & 69 & 78 & 88 & 88 \\
\hline
\end{tabular}

$0.05 \mathrm{mg} \cdot \mathrm{kg}^{-1}$ (7 patients) or pyridostigmine $0.25 \mathrm{mg} \cdot \mathrm{kg}^{-1}(7$ patients). Venous blood samples were then drawn at $1,2,3,5,7,10,20$, $30,45,60,75,90,120,150,180,210,240$ and 270 minutes for estimation of serum cholinesterase activity. The neuromuscular block was antagonized satisfactorily in all patients.

Three ml samples of blood were collected each time, allowed to clot, and the serum was collected. Serum cholinesterase activity was estimated by the colorimetric method described by Ellman and colleagues ${ }^{5}$ within six hours of collection of the blood samples. The serial estimations in each group were analysed statistically using a paired ' $t$ ' test and the two groups were compared using a non-paired ' $t$ ' test, $\mathbf{P}<$ 0.05 being taken as significant.

\section{RESULTS}

There were seven patients of similar age and weight (Table I) in each group and serum cholinesterase activity before administration of neostigmine or pyridostigmine was similar in the groups. Following the administration of neostigmine the mean cholinesterase activity decreased from 2.56 units per $\mathrm{ml}$ (normal range in our laboratory being $1.9-3.8 \mathrm{IU} / \mathrm{ml}$ ) to 0.17 units per $\mathrm{ml}$ ( 6.6 per cent of control activity) at one minute (Figure 1). Thereafter the enzyme activity started to rise, reaching a level of approximately 50 per cent $\left(\mathrm{I}_{50}\right.$, Table I) by 20 minutes. The enzyme activity was significantly below the control levels at all times except at 270 minutes.

The serum cholinesterase activity following pyridostigmine administration decreased from a control value of $2.58 \mathrm{IU} / \mathrm{ml}$ to a minimum of $0.65 \mathrm{IU} / \mathrm{ml}$ (approx 25 per cent of control level) by two to three mintues. The activity was significantly depressed throughout the four and a

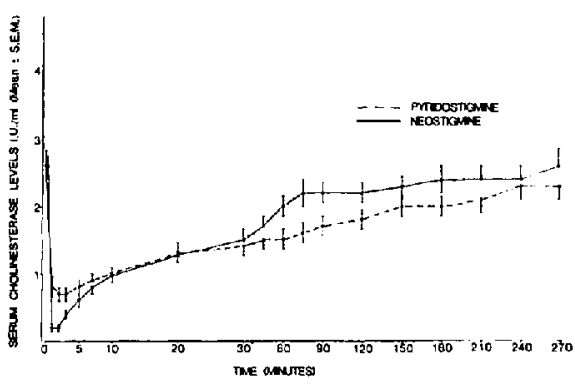

Figure 1 Mean serum cholinesterase activity (IU/ml) over 270 minutes following reversal with neostigmine (7 patients) and pyridostigmine (7 patients).

half hours of measurement. Although the time to 50 per cent recovery of the enzyme activity was again 20 minutes, it remained below that following neostigmine administration.

Whereas neostigmine administration produced greater depression of enzyme activity than pyridostigmine in the first 10 mintues, significantly so in the first three minutes, the effects of pyridostigmine were greater from 20 mintues onwards; the difference was significant at 60 and 75 minutes.

\section{Discussion}

Previously published reports on the duration of effects of anticholinesterase drugs on serum cholinesterase activity have been conflicting.

Both Stoelting ${ }^{6}$ and Sunew and Hicks ${ }^{4}$ found the enzyme activities to be significantly depressed for prolonged periods following pyridostigmine administration. Whereas Stoelting ${ }^{6}$ reported that neostigmine did not reduce enzyme activity significantly beyond 10 minutes following its administration, Sunew and Hicks ${ }^{4}$ found the 
activities to be siginficantly depressed at 40 mintues with neostigmine and 30 minutes with pyridostigmine. The present study shows a more profound immediate depression with neostigmine and the depression in enzyme activity was significant up to four hours with this drug. The results with pyridostigmine are more uniform in our study as well as the other studies. ${ }^{4,6}$ It is possible that both these groups of workers would have observed depression in enzyme activities similar to those described here, had they studied the effect for longer periods. This study is in agreement with the findings of Stoelting ${ }^{6}$ about effects of pyridostigmine in that the enzyme activity showed greater effect than with neostigmine. However we noticed this from 30 minutes onwards, in contrast to the findings of Stoelting, who found such effect just after the first minutes of administration of these drugs. More surprising in the study of Stoelting ${ }^{6}$ is the rapid recovery in the enzyme activities following neostigmine. This is not only in contrast to our findings here as well as those of Sunew and Hicks ${ }^{4}$ but is not supported by the pharmacokinetic data on neostigmine which show its halflife to be about 30 minutes. ${ }^{7}$ More persistent effects of pyridostigmine would be in keeping with its long half-life ${ }^{8}$ as well as persistent effects on true cholinesterase and its long duration of action. ${ }^{9}$

It is possible that serum cholinesterase activity may have been affected by the use of pancuronium as a relaxant in the present study, ${ }^{10}$ but it is presumed that both groups have been similarly affected.

Are the effects of this depression in enzyme activity significant? A statistical significance may not be of clinical relevance here. Sunew and Hicks $^{4}$ showed a three-fold prolongation of succinylcholine paralysis following neostigmine and a two-fold prolongation following pyridostigmine administration. The depression in enzyme activity was greater, however, with pyridostigmine. A case reported by Bentz and Stoelting ${ }^{11}$ showed a very prolonged response to succinylcholine when administered one hour after antagonism of a previous pancuronium block by pyridostigmine. Serum cholinesterase activity was not determined in this patient until the third day after the administration of succinylcholine, when this was markedly depressed.

From the recent study of Sunew and Hicks ${ }^{4}$ and those of others ${ }^{12,13}$ it is apparent that a prolongation of succinylcholine paralysis can result from the administration of anticholinester- ase but it is doubtful whether depression in serum cholinesterase activities can be solely responsible. Apparently the enzmye needs to be depressed by more than 75 per cent before a significant prolongation occurs. ${ }^{12,13}$

It is wise, however, to consider the immediate period of about 20 to 30 minutes following anticholinesterase drug administration as a time when a prolonged period of paralysis may follow succinylcholine administration. One may either avoid using succinylcholine or reduce the dosage considerably, perhaps for longer periods if pyridostigmine has been used in large doses.

Since the effects of neostigmine on acetylcholinesterase (red cell cholinesterase) are quite intense ${ }^{2}$ and those of pyridostigmine quite prolonged, ${ }^{9}$ a relatively larger dose of a nondepolarising relaxant may be needed to reinduce neuromuscular block if required. This aspect of the interaction of anticholinesterase drugs and nondepolarising muscle relaxants does not appear to have been specifically studied.

\section{REFERENCES}

1. MiLlER, R.D. Antagonism of neuromuscular block. Anesthesiology 44: 318 (1976).

2. BARROW, M.E.H. \& JohnSON, J.K. A study of anticholinesterase and anticurare effects of some cholinesterase inhibitors. Br. J. Anaesth. 38: 420 (1966).

3. MCInTYRe, J.W.R. \& Campbell, D.J. Serum cholinesterase in anaesthesia with reference to neostigmine, fentanyl and dihydrobenzperidol. Can. Anaesth. Soc. J. 13: 557 (1966).

4. SUNEW, K.Y. \& Hicks, R.G. Effects of neostigmine and pyridostigmine on duration of succinylcholine action and pseudocholinesterase activity. Anesthesiology 49:188 (1978).

5. Ellman, G.L., Courtney, K.D., Andres, V.J. \& FEATHERSTONE, R.M. A new and rapid colorimetric determination of acetylcholinesterase activity. Biochem. Pharmacol. 7: 88 (1961).

6. StOELting, R.K. Serum cholinesterase activity following pancuronium and antagonism with neostigmine or pyridostigmine. Anesthesiology 45: 674 (1976)

7. Williams, N.E., Calyey, T.N. \& Chan, K. Clearance of neostigmine from the circulation during the antagonism of neuromuscular block. Br. J. Anaesth. 50: 1065 (1978).

8. Baker, P.R., Calvey, T.N., Chan, K., MaCNEE, C.M. \& TAYLOR, K. Plasma clearance of neostigmine and pyridostigmine in the dog. Br. J. Pharmacol. 63: 509 (1978).

9. Miller, R.D., VANNYHUIS, L.S., EgER, E.I., VITEZ, T.Z. \& WAY, W.L. Comparative times to peak effect and durations of action of neostigmine and pyridostigmine. Anesthesiology 41:27 (1974).

10. Stovner, J., Ofledal, N. \& Holmboe, J. The 
inhibitions of cholinesterase by pancuronium. Br. J. Anaesth. 47: 949 (1975).

11. Bentz, E.W. \& Stoelting, R.K. Ptolonged response to succinylcholine following pancuronium reversal with pyridostigmine. Anesthesiology 44: 258 (1976).
12. ARgent, D.E., Dinnick, O.P. \& Hobinger, F. Prolonged apnoea after suxamethonium in man. Br. J. Anaesth. 27: 24 (1955).

13. VICKERS. M.D. The cholinesterases and their significance to the anaesthetist using muscle relaxants. Br. J. Anaesth. 35: 528 (1963).

\section{RÉsumé}

On a mesuré l'activité de la cholinestérase sérique durant 270 minutes après l'administration de néostigmine ou de pyridostigmine, ces agents ćtant utilisés pour lever un bloc au pancuronium. Deux groupes de sept patients chacun ont été étudiés, ceux du premier groupe ayant reçu de la néostigmine et ceux du second groupe de la pyridostigmine. L'activité de la cholinestérase était significativement diminué durant quatre heures après l'administration de néostigmine et durant toute la durée de l'étude (270 minutes) dans le cas de la pyridostigmine. Les effets immédiats de la néostigmine étaient plus marqués que ceux de la pyridostigmine. Trente minutes après son administration, ceux de la pyridostigmine étaient plus importants. Les applications cliniques de ces résultats sont discutées. 